\title{
Relacjonowanie prezydenckiej kampanii wyborczej w 2015 roku przez „Wiadomości” TVP1: zrównoważone czy stronnicze?
}

\begin{abstract}
Streszczenie: We współczesnych demokracjach media pełnią kilka istotnych ról: informowanie wyborców o kandydatach i ich programach, tłumaczenie działań kandydatów i ich oponentów, kontrolowanie rządzących oraz mobilizację polityczną wyborców. Wiedza elektoratu o kandydatach biorących udział w wyborach, ocena ich kandydatur, a w konsekwencji także decyzja o głosowaniu na określonego kandydata, pozostają w określonym związku z tym, jaki obraz danego kandydata został wykreowany w mediach. Szczególną rolę odgrywa tu telewizja, gdyż $81 \%$ respondentów wskazało, że głównym źródłem informacji na temat polityki są dla nich telewizyjne programy informacyjne.

Artykuł przedstawia wyniki badań analizy zawartości „Wiadomości” TVP1 przed wyborami prezydenckimi w 2015 roku w Polsce. Celem badań była ocena, czy kampania relacjonowana była w sposób zrównoważony czy stronniczy. Analizie poddano widoczność medialną oraz wydźwięk newsów w najchętniej oglądalnym telewizyjnym programie informacyjnym.
\end{abstract}

Słowa kluczowe: stronniczość medialna, równowaga medialna, telewizyjne programy informacyjne, relacjonowanie wyborów prezydenckich, analiza zawartości

\section{Wprowadzenie}

$\mathbf{W}$ e współczesnych demokracjach media pełnią kilka istotnych ról. Za najważniejsze uznać należy: informowanie wyborców o kandydatach i ich programach, tłumaczenie działań kandydatów i ich oponentów, kontrolowanie rządzących oraz mobilizację polityczną wyborców (Esser, Strömbäck, De Vreese, 2011, s. 139).

Wątpliwości badaczy nie budzi fakt, że silny związek pomiędzy mediami a procesami politycznymi tłumaczyć można między innymi postępującą mediatyzacją. Gianpietro Mazzoleni podkreśla, że media zmieniły całokształt życia społecznego w takim stopniu, iż zasadne jest posługiwanie się pojęciem „,mediatyzacja społeczeństwa”. Włoski badacz określa w ten sposób proces obejmujący wszystkie sfery życia społecznego, począwszy od życia rodzinnego, codziennych relacji międzyludzkich po zjawiska występujące we wszelkich organizacjach, także politycznych czy gospodarczych. Istotny pozostaje także kierunek postępujących zmian, charakteryzujący się wzrostem obecności mediów w życiu społeczeństw (Mazzoleni, 2008, s. 3052-3054).

Mediatyzacja polityki jest przedmiotem zainteresowania badaczy zarówno zajmujących się głównie procesami politycznymi, jak i koncentrujących swoje wysiłki badawcze na zagadnieniach dotyczących mediów (por. Hjarvard, 2013, s. 41 i n.; Mazzoleni, 2015, s. 378-380; Strömbäck, Esser, 2014a, 2014b, s. 3 i n.). Ich rozważania pozostają zgodne w odniesieniu do przekonania o wzrastającym znaczeniu mediów i ich wieloaspektowych skutkach dla procesów politycznych, instytucji, organizacji i podmiotów polityki. Nie może zatem dziwić także wzrost zainteresowania badaczy 
analizą tego, jak polityka jest prezentowana w mediach, zwłaszcza w okresie kampanii wyborczych.

Przyjmując zarysowaną perspektywę badawcza, uznać można, iż wiedza elektoratu o kandydatach biorących udział w wyborach, ocena ich kandydatur, a w konsekwencji także decyzja o głosowaniu na określonego kandydata, pozostają w określonym związku z tym, jaki obraz danego kandydata został wykreowany w mediach. Badania empiryczne przeprowadzone w Polsce w 2015 roku na kilka miesięcy przed wyborami prezydenckimi dowodza, że mimo rosnącego znaczenia internetu, telewizja wciąż pozostaje głównym źródłem informacji o polityce. W przeprowadzonym na ogólnopolskiej, reprezentatywnej próbie 1000 mieszkańców Polski przez TNS OBOP badaniu 81\% respondentów wskazało, że głównym źródłem informacji na temat polityki są dla nich telewizyjne programy informacyjne (Raport). Wynik ten pozwala sądzić, że programy te stanowią także ważne i opiniotwórcze źródło informacji dotyczących kampanii wyborczych, jakie miały miejsce w 2015 roku.

Analizy zawartości telewizyjnych programów informacyjnych prowadzone są na świecie dość często, zaś rozliczne wyniki badań empirycznych sprzyjają także formułowaniu koncepcji teoretycznych (liczne przykłady: Gulati, Just, Crigler, 2004, s. 238 i n.). Prym w tym zakresie wiodą uczeni amerykańscy, jednak również w Europie prowadzone są badania, często także porównawcze, które analizują sposób relacjonowania kampanii wyborczych w telewizji (zob. Farnsworth, Lichter, 2011; Strömbäck, Kaid, 2008; Maier, Strömbäck, Kaid, 2011). W Polsce analiza zawartości telewizyjnych programów informacyjnych nie jest prowadzona systematycznie, jednak istnieją znaczące opracowania między innymi Mariusza Kolczyńskiego i Marka Mazura, Bartłomieja Łódzkiego czy Ewy Nowak i Rafała Riedla, które gromadzą wyniki badań przekazów telewizyjnych w okresie kampanii wyborczych (Kolczyński, Mazur, 2007; Łódzki, 2010; Nowak, Riedel, 2008).

Celem niniejszego opracowania jest prezentacja wyników analizy zawartości głównego wydania najpopularniejszego w Polsce w okresie prezydenckiej kampanii wyborczej telewizyjnego programu informacyjnego, czyli „Wiadomości” emitowanych przez publicznego nadawcę TVP1. Badania obejmują analizę ilościową oraz ilościowo-jakościową ukierunkowaną na ocenę tego, czy „Wiadomości” TVP były neutralne w prezentowaniu przebiegu kampanii i kandydatów, czy też można im przypisać stronniczość, a więc sprzyjanie lub nieprzychylność względem któregoś z kandydatów.

\section{Metodologia}

Analiza zawartości mediów jest popularną techniką badawczą, która jak wskazywał jeden z jej prekursorów, Bernard Berelson, ma na celu obiektywny, systematyczny i ilościowy opis jawnej treści komunikatu (Berelson, 1952, s. 18). Badaniu postanowiono poddać zawartość najpopularniejszego wieczornego telewizyjnego programu informacyjnego w okresie prezydenckiej kampanii wyborczej. Według danych Nielsen Audience Measurement program „Wiadomości” TVP cieszył się największą oglądalnością w okresie prezydenckiej kampanii wyborczej. W poniższej tabeli zestawiono dane na temat oglądalności wieczornych programów informacyjnych w marcu, kwietniu i maju 
2015 roku. Do badania wybrano okres dokładnie dwóch miesięcy poprzedzających datę drugiej tury wyborów prezydenckich. Badaniem objęto zatem wszystkie wydania „Wiadomości” TVP1 od 24 marca do 23 maja 2016 roku. Ogółem zarejestrowano 61 audycji. Jako jednostkę rejestracji przyjęto pojedynczą informację (newsa), zaś jednostką pomiaru była 1 sekunda.

Tabela 1

Oglądalność głównych telewizyjnych programów informacyjnych w okresie marzec-maj 2015 roku

\begin{tabular}{|l|c|c|c|}
\hline \multicolumn{1}{|c|}{ Tytul } & Marzec 2015 & Kwiecień 2015 & Maj 2015 \\
\hline Wiadomości TVP1 19.30 & 3840751 & 3430403 & 3067926 \\
\hline Fakty TVN 19.00 & 3484819 & 2942063 & 2581225 \\
\hline Wydarzenia Polsat 18.50 & 2481679 & 2220331 & 2069669 \\
\hline \hline
\end{tabular}

Źródło: Opracowanie własne na podstawie danych Nielsen Audience Measurement dla portalu wirtualnemedia.pl; M. Kurdupski, ,, Wiadomości” na czele dzienników w marcu. ,, Wydarzenia” stracity najwięcej, http:// www.wirtualnemedia.pl/artykul/wiadomosci-na-czele-dziennikow-w-marcu-wydarzenia-stracily-najwiecej, 21.09.2016; M. Kurdupski, ,, Wiadomości” liderem, mimo utraty 200 tys. widzów. „,Fakty” stracity w TVN 400 tys. ogladajacych, http://www.wirtualnemedia.pl/artykul/wiadomosci-liderem-mimo-utraty-200-tyswidzow-fakty-stracily-w-tvn-400-tys-ogladajacych, 21.09.2016; M. Kurdupski, , Teleexpress” zyskat 360 tys. oglądajacych. ,Fakty” $i$,, Wiadomości” stracity widzów, http://www.wirtualnemedia.pl/artykul/teleexpresszyskal-360-tys-ogladajacych-fakty-i-wiadomosci-stracily-widzow, 21.09.2016.

Na potrzeby badań stworzono klucz kategoryzacyjny obejmujący dwie części. Pierwsza z nich odnosiła się do ilościowych parametrów audycji i pojedynczych newsów, takich jak czas trwania audycji, odsetek newsów poświęconych problematyce wyborów prezydenckich, pozycjonowanie newsów wyborczych w strukturze audycji czy odsetek czasu całej audycji poświęcony problematyce wyborczej. Gromadzi ona zatem dane umożliwiające wstępne zapoznanie się ze zgromadzonym materiałem. Druga część klucza odnosiła się do ilościowo-jakościowych elementów analizy audycji, przy czym uwagę skoncentrowano tu w szczególności na postawionym pytaniu badawczym o neutralność przekazu informacji dotyczących poszczególnych kandydatów na urząd prezydenta.

Nie ulega wątpliwości, że analiza jakościowa stanowi o wiele większe wyzwanie metodologiczne i obarczona jest znacznie większym wysiłkiem, albowiem to od oceny badacza i konstrukcji samego klucza uzależniony może być ostateczny wynik całego badania. Trudności te mają dwojaką naturę. $Z$ jednej strony to wiedza, doświadczenie i subiektywny punkt widzenia badacza mogą mieć wpływ na zakwalifikowanie określonego newsa jako bardziej lub mniej faworyzującego danego kandydata. Z drugiej zaś strony ogromną rolę odgrywa wybór odpowiednich kategorii oraz ich precyzyjny opis, który dawałby gwarancję, że każdy badacz, który chciałby powtórzyć procedurę badawczą uzyskałby w jej efekcie takie same wyniki.

Zarysowane trudności metodologiczne skłoniły uczonych zajmujących się analizą zawartości telewizyjnych programów informacyjnych do podjęcia wysiłku w celu ujednolicenia wybranych kategorii analitycznych oraz stworzenia na potrzeby przyszłych badań wspólnych konceptualizacji i operacjonalizacji (Esser i in., 2011, s. 139 i n.). Istotną zaletą tej propozycji uczonych z Network of European Political Communication 
Scholars jest porównywalność wyników analiz zawartości newsów w ramach określonej konceptualizacji. W przeprowadzonych badaniach wykorzystana została koncepcja pomiaru równowagi newsów (political balance in the news) rozumiana jako przeciwieństwo stronniczości (partisan media bias), czyli uprzywilejowania w zakresie prezentowania określonej partii lub polityka (Hopmann, Van Aelst, Legnante, 2011, s. 241). Poza samą operacjonalizacją kategorii neutralności zaproponowano także narzędzie badawcze, które stosowane przez różnych badaczy zawartości newsów pozwala na porównywanie ich analiz, a ponadto daje szansę na wysoki poziom obiektywizmu wyników badań. W przeprowadzonej analizie w obszarze badań ilościowo-jakościowych wykorzystane zostało narzędzie zaproponowane przez Davida N. Hopmanna, Petera Van Aelsta i Guido Legnante. Poniższa tabela przedstawia zmodyfikowaną na potrzeby niniejszego badania wersję klucza kategoryzacyjnego wykorzystanego do analizy zawartości „Wiadomości” TVP1.

\section{Klucz kategoryzacyjny do badania zawartości „Wiadomości” TVP1 - analiza ilościowo-jakościowa}

\begin{tabular}{|c|l||}
\hline Kategoria & \multicolumn{1}{|c|}{ Instrukcja kodowania } \\
\hline Widoczność & W badaniu kodowani są wszyscy polscy politycy, którzy występują w newsach. \\
& Zmienna może zostać zakodowana na jeden z czterech sposobów: \\
& (W) „wymieniony” - wspomniane zostaje nazwisko polityka lub jego funkcja w taki sposób, \\
& że oczywistym jest, o kim jest mowa, przy czym polityk nie jest pokazywany, \\
& (C) „cytowany” - polityk nie jest pokazywany, ale wspomina się o nim cytując treść jego \\
& wypowiedzi, \\
& (P) „,pokazany”- polityk jest widoczny w newsie, \\
(M),,mówi”- polityk wypowiada jakiekolwiek słowa, które widz może rozpoznać, zrozumieć. & Kodowana jest najwyższa z kategorii (czyli jeśli polityk został wymieniony „W” i pokazany \\
& „P”, news zakodowany zostaje jako „P”). \\
\hline Wydźwięk & $\begin{array}{l}\text { W badaniu kodowani są wszyscy polscy politycy, którzy występują w newsach. } \\
\text { Zmienna może zostać zakodowana na jeden z czterech sposobów: } \\
\text { (K) korzystny - news ma jednoznacznie pozytywną dla polityka konotację, } \\
\text { (N) niekorzystny - news ma jednoznacznie negatywną dla polityka konotację, } \\
\text { (A) ambiwalentny - news może zostać odebrany zarówno pozytywnie, jak i negatywnie, } \\
\text { (Ne) neutralny - news nie zawiera ani pozytywnych, ani negatywnych znaczeń czy konotacji. }\end{array}$ \\
\hline
\end{tabular}

Źródło: Opracowanie własne na podstawie D. N. Hopmann, P. Van Aelst, G. Legnante, Political balance in the news: A review of concepts, operationalizations and key findings, ,Journalism” 2011, t. 13, nr 2, s. 257.

\section{Wyniki}

W analizowanych głównych wydaniach „Wiadomości” TVP nadawanych w okresie dwóch miesięcy poprzedzających dzień drugiej tury wyborów prezydenckich stosunkowo rzadko wystąpiła sytuacja, w której żaden news nie był poświęcony wyborom prezydenckim. Pamiętać należy przy tym, iż wśród 61 wydań, będących przedmiotem niniejszego badania, znajdują się także audycje nadawane w okresie ciszy wyborczej przed dniem I tury wyborów oraz w dniu samej elekcji, a także w dniu poprzedzającym II turę głosowania. W tych wydaniach audycji materiały poświęcone wyborom nie mogły się zatem znaleźć niezależnie od intencji autorów programu. W sumie materiały poświęco- 
ne kampanii wyborczej pojawiły się w 49 wydaniach „Wiadomości” TVP, co stanowi ponad $80 \%$ wszystkich analizowanych wydań programu. Szczegóły dotyczące rozkładu w kolejnych tygodniach wydań zawierających informacje dotyczące prezydenckiej kampanii wyborczej przedstawione zostały na poniższym wykresie.

Wykres 1. Liczba wydań „Wiadomości” TVP w kolejnych tygodniach badania, w których pojawily się newsy dotyczące prezydenckiej kampanii wyborczej

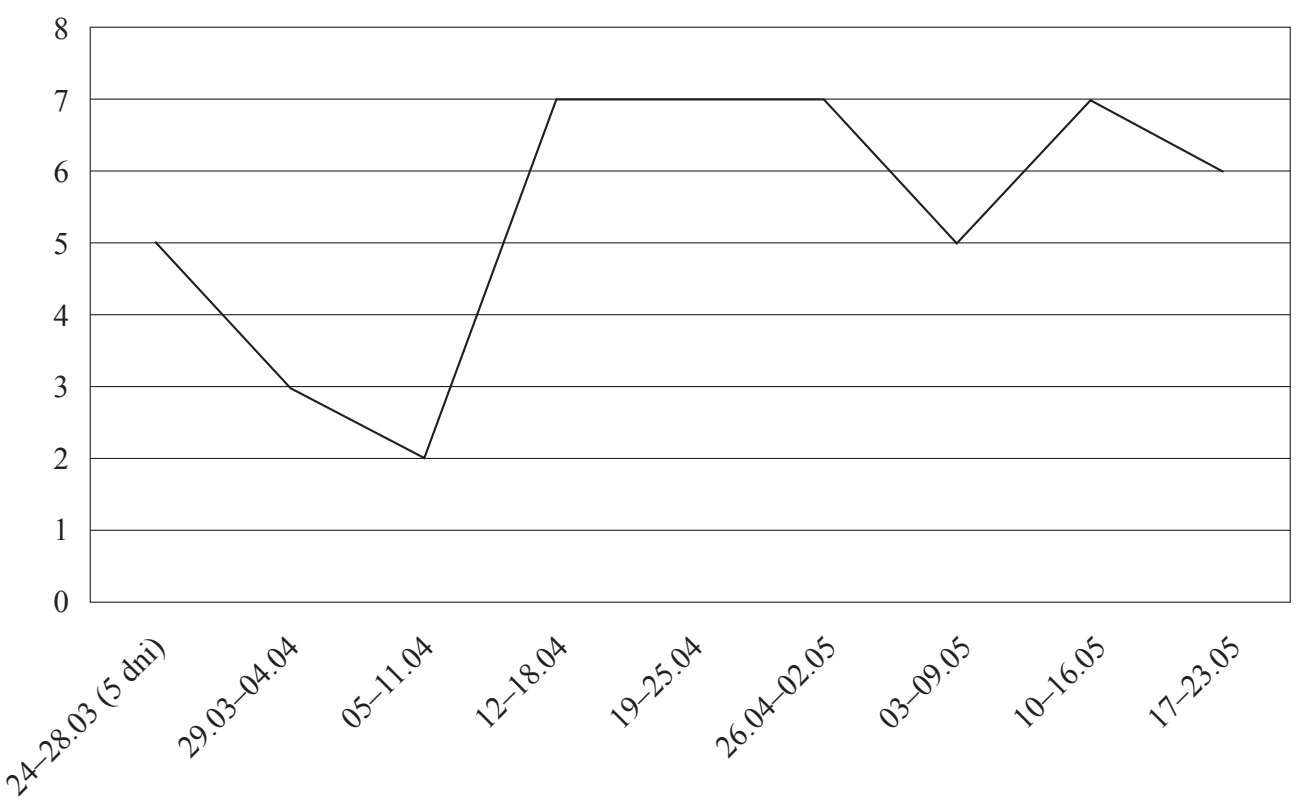

Źródło: Opracowanie własne.

Na podstawie powyższych danych uznać można, że prezydencka kampania wyborcza traktowana była przez twórców programu jako wydarzenie doniosłe, któremu poświęcono uwagę w zdecydowanej większości wydań audycji. Podnieść należy także, iż brak materiałów poświęconych wyborom miał miejsce, poza okolicznościami wspomnianymi wyżej, głównie w dniach, w których w ogóle tematy polityczne schodziły na dalszy plan, w szczególności w okresie Świąt Wielkanocnych oraz rocznicy śmierci papieża. Istotne tendencje ilustruje także analiza liczby newsów, jakie w kolejnych dniach poświęcono wyborom. W przypadku I tury zainteresowanie wyborami było tym większe, im bliższa była data głosowania. Szczegóły prezentuje wykres 2.

Z zaprezentowanych danych wynika także, że w okresie pomiędzy pierwszą a drugą turą wyborów liczba newsów poświęconych kampanii wyborczej była większa niż przed pierwszą turą wyborów. Od 11 do 21 maja tylko raz liczba wiadomości poświęconych wyborom była niższa od 3 . Wskazane tendencje dotyczące rozkładu w czasie informacji dotyczących kampanii wyborczej w programie informacyjnym TVP potwierdza także analiza czasu trwania wszystkich newsów dotyczących wyborów. Poddane analizie wydania „Wiadomości” TVP trwały łącznie 26 godzin, 12 minut i 6 sekund, w tym 6 godzin, 5 minut i 15 sekund poświęcono tematyce wyborczej, co stanowiło $23 \%$ całego badanego 
materiału. W analizowanym okresie poprzedzającym pierwszą turę wyborów prezydenckich $17 \%$ czasu „Wiadomości” TVP poświęciły problematyce wyborczej, zaś w okresie pomiędzy pierwszą a drugą turą wyborczą aż $46,33 \%$ czasu trwania audycji poświęcono problematyce wyborczej. Szczegółowe dane prezentuje poniższa tabela. Warto podkreślić zatem, że z jednej strony, zgodnie z oczekiwaniami, im bliżej do dnia elekcji, tym więcej czasu poświęcano tematyce kampanii. $Z$ drugiej zaś strony to $\mathrm{w}$ okresie kampanii wyborczej przed drugą turą wyborów „Wiadomości” TVP traktowały wybory jako wydarzenie niezwykle ważne, poświęcając mu niemal połowę czasu antenowego. Potwierdza to także szczegółowa analiza relacji długości trwania całego programu do czasu poświęconego kampanii wyborczej w badanym okresie, co uwidocznione zostało na wykresie 3 .

\section{Wykres 2. Liczba wszystkich newsów oraz newsów dotyczących prezydenckiej kampanii wyborczej w „Wiadomościach” TVP w kolejnych dniach badania}

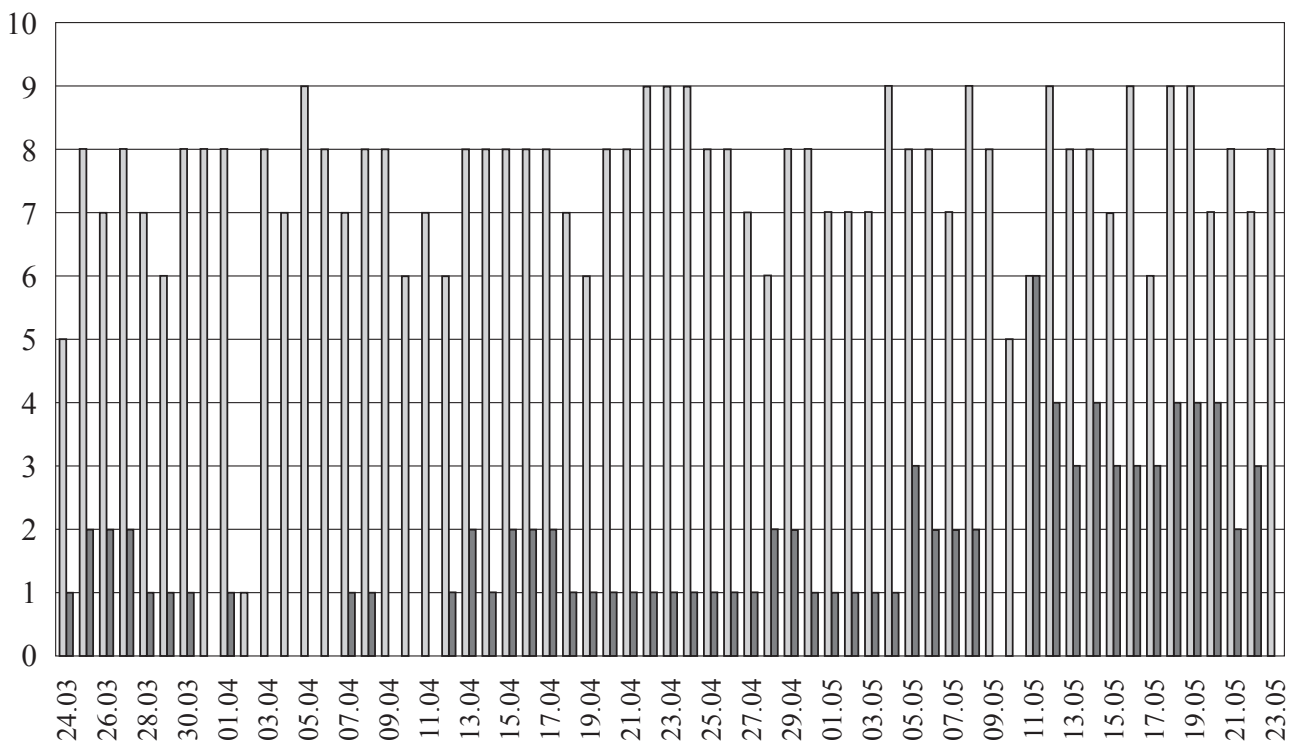

Źródło: Opracowanie własne.

Tabela 3

Czas trwania programu „Wiadomości” TVP oraz newsów poświęconych prezydenckiej kampanii wyborczej w analizowanym okresie

\begin{tabular}{|l|c|c|c||}
\hline \multicolumn{1}{|c|}{ Badany okres } & $\begin{array}{c}\text { Czas trwania wszyst- } \\
\text { kich badanych wydań } \\
\text { „Wiadomości” TVP }\end{array}$ & $\begin{array}{c}\text { Czas trwania newsów } \\
\text { poświęconych prezy- } \\
\text { denckiej kampanii } \\
\text { wyborczej }\end{array}$ & $\begin{array}{c}\text { Odsetek czasu poświę- } \\
\text { conego prezydenckiej } \\
\text { kampanii wyborczej }\end{array}$ \\
\hline Przed I turą (24.03-10.05) & $20: 38: 31$ & $03: 30: 42$ & $17,01 \%$ \\
\hline Przed II turą (11.05-23.05) & $05: 33: 35$ & $02: 34: 33$ & $46,33 \%$ \\
\hline Razem & $26: 12: 06$ & $06: 05: 15$ & $23,23 \%$ \\
\hline
\end{tabular}

Źródło: Opracowanie własne. 


\section{Wykres 3. Czas trwania wszystkich newsów oraz newsów dotyczących prezydenckiej kampanii wyborczej w „Wiadomościach” TVP w kolejnych dniach badania}

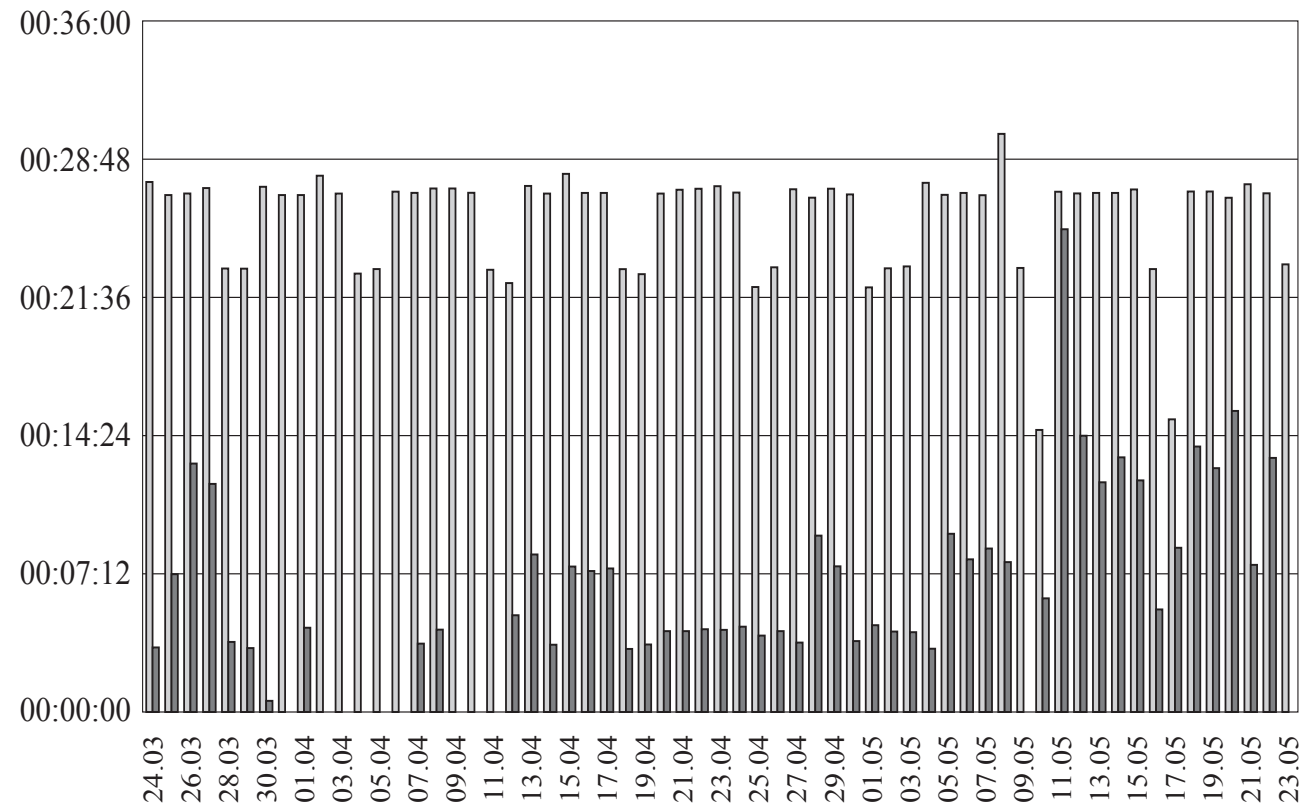

\section{czas trwania programu}

czas poświęcony problematyce wyborczej

Źródło: Opracowanie własne.

Podobne tendencje ilustruje analiza pozycjonowania newsów dotyczących kampanii wyborczej w badanych wydaniach „Wiadomości” TVP. Program otwierała informacja dotycząca wyborów w przypadku większości wydań pomiędzy pierwszą a drugą turą głosowania oraz w tygodniu poprzedzającym pierwszą turę. W okresie wcześniejszym informacje na temat kampanii wyborczej rzadziej występowały jako pierwsze. Warto podkreślić jednak, że w przypadku pozycjonowania newsów dodatkowym czynnikiem decydującym o ich kolejności pozostaje istnienie ważnego, specyficznego czy spektakularnego wydarzenia, które jest na tyle elektryzujące, czy interesujące, że to od niego rozpoczyna się program. Egzemplifikację takiego spektakularnego newsa stanowi informacja rozpoczynająca „Wiadomości” 19 kwietnia dotycząca tego, że dyrektor FBI w swojej wypowiedzi odpowiedzialnością za holocaust obciążył Polaków. Przez cały tydzień od tego zdarzenia „Wiadomości” nie rozpoczynały się newsem dotyczącym kampanii wyborczej, ale właśnie spekulacjami i zapowiedziami dotyczącymi tego, czy dyrektor FBI powinien przeprosić, czy wyrazi słowa ubolewania oraz kto i co powinien uczynić, jeżeli jednak nie przeprosi. Pozycjonowanie newsów w programie potwierdza zatem w dużej mierze tezę, że materiałom na temat kampanii przypisywano tym większą wagę, im bliżej było do dnia samych wyborów. Wyrażało się to w częstotliwości pojawiania się takich newsów, ich liczbie, a także w częstotliwości rozpoczynania od nich głównego wydania „Wiadomości” TVP. Szczegółowe dane na ten temat znajdują się na wykresie poniżej. 


\section{Wykres 4. Liczba wydań „Wiadomości” TVP, które zaczynały się od informacji na temat prezydenckiej kampanii wyborczej}
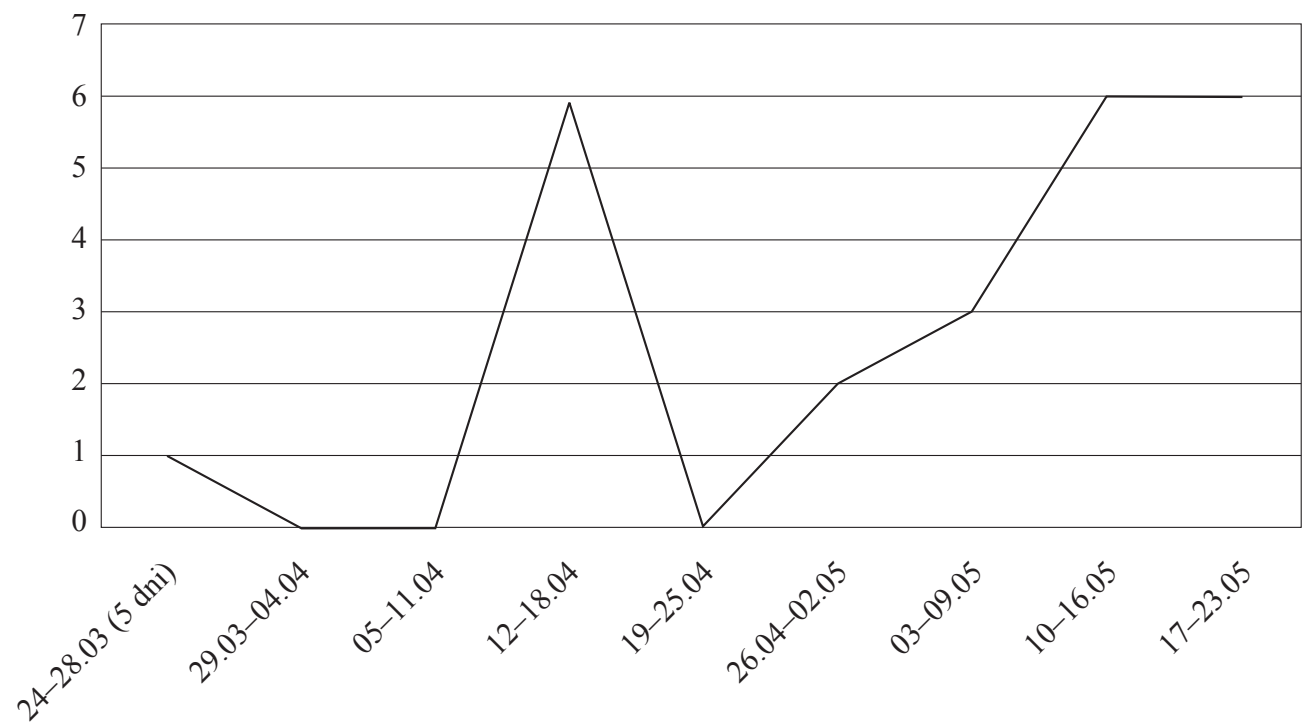

Źródło: Opracowanie własne.

W dalszej części badania analizie poddano problem neutralności prezentacji kandydatów na urząd prezydenta w głównych wydaniach programu „Wiadomości” TVP. Pierwszym czynnikiem, który został wzięty pod uwagę była widoczność kandydatów. Już na wstępie należy zwrócić uwagę na fakt, iż jeden z kandydatów na urząd prezydenta, Bronisław Komorowski, pełnił w czasie kampanii wyborczej także funkcję głowy państwa. Taki stan rzeczy prowadził do sytuacji jego obecności w programach informacyjnych w podwójnej roli: prezydenta i kandydata. Często nie istniała ponadto obiektywna możliwość oddzielenia materiałów prezentujących Bronisława Komorowskiego w każdej z tych ról. Polityk ten niejednokrotnie prezentowany był w miejscu, w którym jego obecność wynikała z pełnionego już urzędu, ale wypowiadał się tam także jako kandydat. W toku badania w kluczu kategoryzacyjnym wyodrębniono szczególną grupę newsów, które obejmowały te przypadki, w których Bronisław Komorowski występował wyłącznie w roli głowy państwa. W toku badania udało się wskazać 18 takich newsów. Tytułem egzemplifikacji wskazać należy informację prezentującą wypowiedź prezydenta Komorowskiego związaną z obchodami rocznicy likwidacji obozów w Kozielsku, Starobielsku i Ostaszkowie przez NKWD czy życzenia prezydenta z okazji Świąt Wielkanocnych, przedstawiane zwyczajowo $\mathrm{w}$ programie informacyjnym w każdym roku, nie tylko wyborczym, przez każdego urzędującego prezydenta. Mając jednak na względzie dążenie do możliwie najbardziej obiektywnego wyniku badania, analiza widoczności kandydatów uwzględnia także newsy, w których Bronisław Komorowski występował jako prezydent, a nie jako kandydat.

Kolejnym zastrzeżeniem, jakie należy uczynić, jest wskazanie, że w badaniu widoczności kandydatów w „Wiadomościach” TVP wzięto pod uwagę jedynie newsy, 
nie uwzględniono natomiast ostatniego fragmentu programu, będącego zapowiedzią innej audycji zatytułowanej „Dziś wieczorem”. Wspomniany fragment „Wiadomości” przedstawiał prowadzącego program z gościem, z którym następnie rozmowa odbywać miała się na antenie programu TVP3. W okresie poprzedzającym pierwszą turę wyborów prezydenckich każdy z kandydatów na prezydenta był jednokrotnie przez około minutę $\mathrm{w}$ studiu programu, a przeprowadzona $\mathrm{z}$ nim rozmowa stanowiła zapowiedź dłuższego wywiadu, jakiego kandydat udzielił już poza programem „Wiadomości”. Pominięto analizę tych fragmentów przy rozpatrywaniu widoczności kandydatów, gdyż wzięcie ich pod uwagę nie zmieniłoby relacji pomiędzy czasem prezentacji kandydatów, a to za sprawą faktu, że każdy z polityków pretendujących do objęcia funkcji głowy państwa był gościem „Wiadomości” tylko dokładnie tyle samo razy, a rozmowa ta trwała $\mathrm{w}$ przybliżeniu tyle samo z każdym $\mathrm{z}$ kandydatów. I tu mówić można o odmiennej sytuacji Bronisława Komorowskiego. W jego przypadku, z uwagi na wspomniany już fakt kandydowania i pełnienia funkcji prezydenta, rozmowa odbyła się w Belwederze, a nie w studiu telewizyjnym, jak miało to miejsce w przypadku pozostałych kandydatów.

W analizowanym materiale badawczym, na co zwracano już uwagę, charakteryzowano oddzielnie widoczność każdego z kandydatów, przy czym wyróżniono cztery formy widoczności: wymienienie nazwiska kandydata (W), zacytowanie jego wypowiedzi (C), pokazanie go (P) lub prezentację jego wypowiedzi (M). Jeżeli w jednym newsie widoczność kandydata można było opisać przy użyciu więcej niż jednej formy zapisywano ją tylko raz, wybierając najwyższą z nich. Jeżeli zaś wypowiedzi kandydata w jednym newsie pojawiały się kilkukrotnie, wówczas liczono je jako oddzielny przypadek widoczności (podnoszący liczbę wystąpień M). W materiale badawczym stosunkowo rzadko odnotowano newsy, w którym polityk został wymieniony, zacytowany czy pokazany, ale choćby przez sekundę nie mówił. Jak wynika $z$ wykresu prezentującego wszystkie formy widoczności medialnej kandydatów na prezydenta RP w „Wiadomościach” TVP w okresie poprzedzającym pierwszą turę wyborów odnotowano 10 przypadków, gdy kandydat został jedynie wymieniony w newsie, przy czym dwukrotnie taka sytuacja miała miejsce w przypadku Bronisława Komorowskiego oraz Magdaleny Ogórek. Ani razu nie odnotowano przypadku, by w newsie kandydat był jedynie cytowany. Każdy kandydat, poza Pawłem Tanajno, przynajmniej raz został pokazany w programie, ale nie zaprezentowano jego wypowiedzi. Najczęściej ze wszystkich kandydatów pokazywano Magdalenę Ogórek, której wizerunek siedmiokrotnie został jedynie pokazany w programie.

Największe zróżnicowanie pomiędzy kandydatami, a jednocześnie największą liczbę wystapień odnotowano w ostatniej analizowanej formie widoczności, czyli prezentowaniu wypowiedzi polityków. Można wyróżnić tutaj trzy grupy kandydatów:

- kandydatów wiodących, czyli Bronisława Komorowskiego i Andrzeja Dudę, których wypowiedzi (oddzielone komentarzem dziennikarskim lub wypowiedzią innego polityka) wystąpiły powyżej 50 razy;

- kandydatów drugiego planu, czyli Janusza Korwin-Mikkego, Janusza Palikota, Magdalenę Ogórek, Pawła Kukiza i Adama Jarubasa, których wypowiedzi wystapiły poniżej 50, ale powyżej 25 razy; 


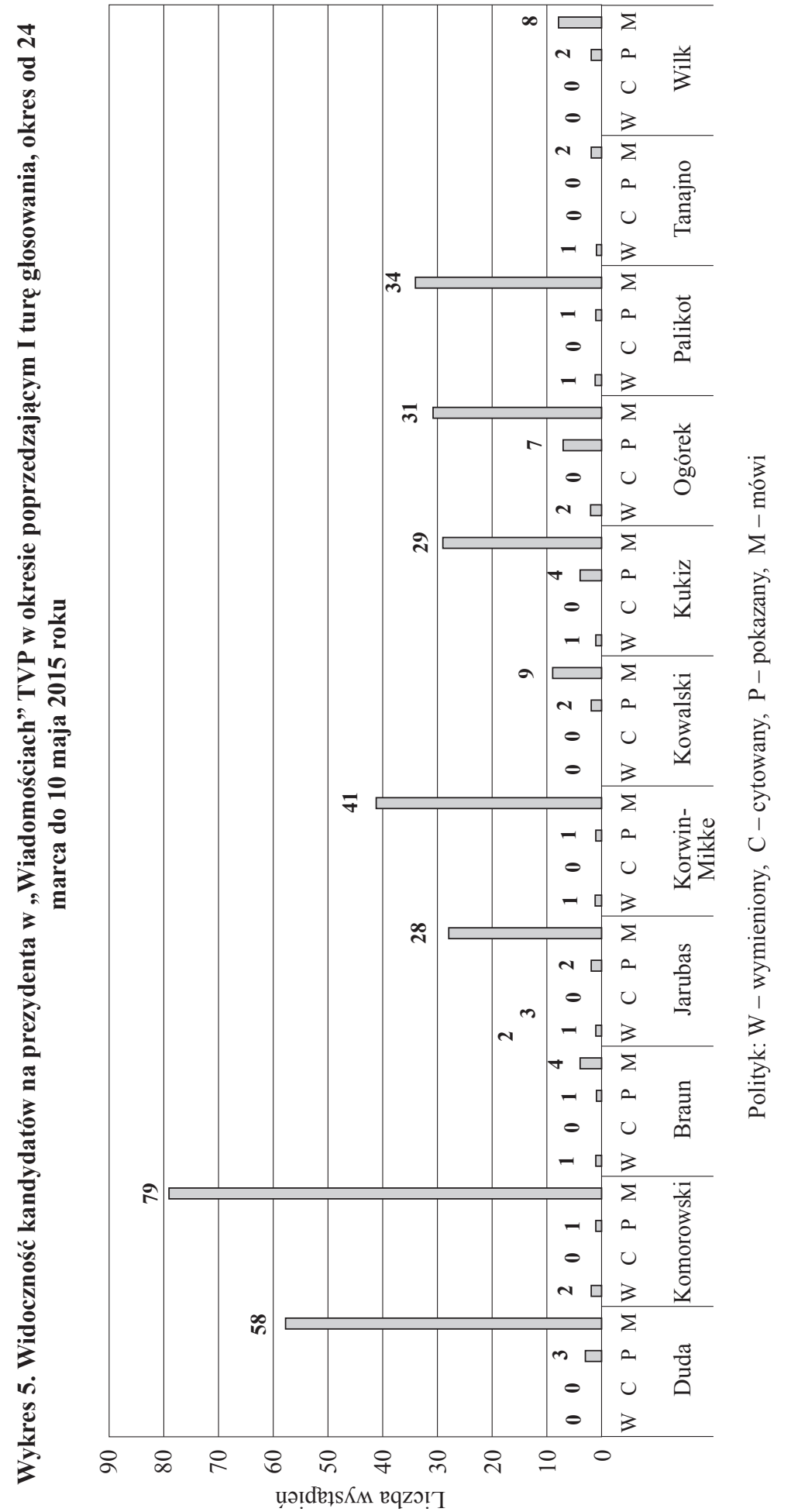


- kandydatów pomijanych, czyli Mariana Kowalskiego, Jacka Wilka, Grzegorza Brauna i Pawła Tanajno, których wypowiedzi wystapiły poniżej 25 razy.

Zaprezentowane wyniki badania, a w szczególności duże zróżnicowanie liczby wystąpień wypowiedzi kandydatów na urząd prezydenta w głównym wydaniu programu, stało się sygnałem do pogłębienia tego obszaru analizy. Dokonano obliczeń, ile dokładnie sekund trwały wypowiedzi kandydatów emitowane w „Wiadomościach” TVP. Wyniki zaprezentowane zostały na poniższym wykresie.

Wykres 6. Czas (w sekundach) wypowiedzi kandydatów w „Wiadomościach” TVP w okresie poprzedzającym I turę głosowania, okres od 24 marca do 10 maja 2015 roku

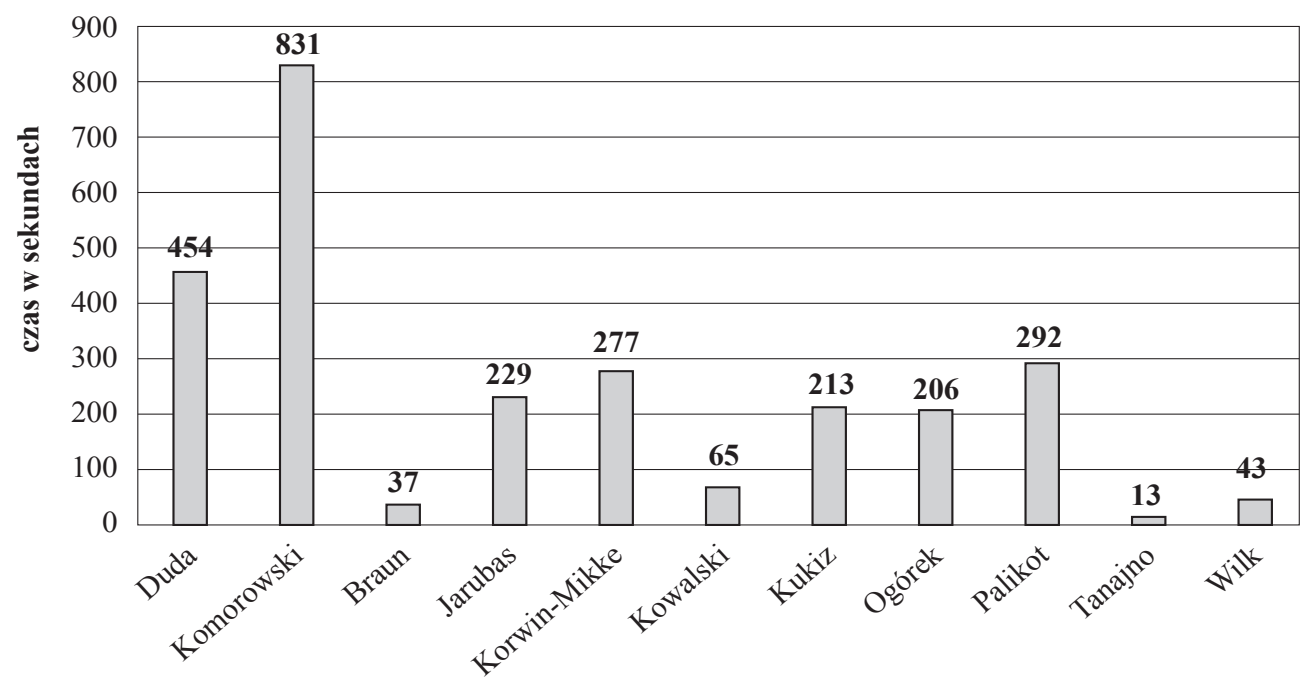

Źródło: Opracowanie własne.

Dane dotyczące czasu wypowiedzi kandydatów silnie korelują z liczbą ich wystąpień, co powiela zarysowany już podział na trzy grupy kandydatów. W pierwszej z nich wyraźna pozostaje przewaga czasu poświęconego Bronisławowi Komorowskiemu, jednak jak wskazywano 18 newsów, które były brane pod uwagę w badaniu, dotyczyło wypowiedzi kandydata w związku z pełnieniem urzędu. Porównanie liczby newsów i czasu ich trwania, nawet uwzględniając to zastrzeżenie, pozwala mówić o przewadze czasu, jaki „Wiadomości” TVP poświęciły na prezentowanie wypowiedzi Bronisława Komorowskiego.

W okresie pomiędzy pierwszą a drugą turą wyborów analogiczne badania dotyczące widoczności kandydatów przeprowadzono w odniesieniu do obydwu kandydatów, którzy dostali się do drugiej tury wyborczej rywalizacji. Ich wyniki zaprezentowano na wykresach 7 i 8.

Analiza widoczności kandydatów w okresie poprzedzającym dzień drugiej tury wyborów prowadzi do wniosku o względnej równowadze dwóch głównych rywali. Urzędujący prezydent wypowiadał się o trzy razy więcej niż jego kontrkandydat, jednak to Andrzej Duda został pokazany o jeden raz więcej niż Bronisław Komorowski. Także analiza czasu, jaki poświęcono na prezentację wypowiadających się kandydatów pozwa- 
la mówić o względnej równowadze. Andrzej Duda wypowiadał się przez 46,7\% czasu poświęconego na wypowiedzi obydwu kandydatów, zaś Bronisław Komorowski przez $53,3 \%$ czasu. W badanym okresie, w odróżnieniu od poprzedzającego pierwszą turę, nie odnotowano wystąpienia specjalnej grupy newsów, które w sposób jednoznaczny prezentowałyby jedynie wypowiedzi Komorowskiego jako prezydenta, a nie jako kandydata na urząd głowy państwa. Bardzo trudno za takie uznać bowiem nawet ogłoszenie referendum dotyczącego między innymi jednomandatowych okręgów wyborczych.

Wykres 7. Widoczność kandydatów na prezydenta w „Wiadomościach” TVP w okresie poprzedzającym II turę głosowania, okres od 11 do 23 maja 2015 roku

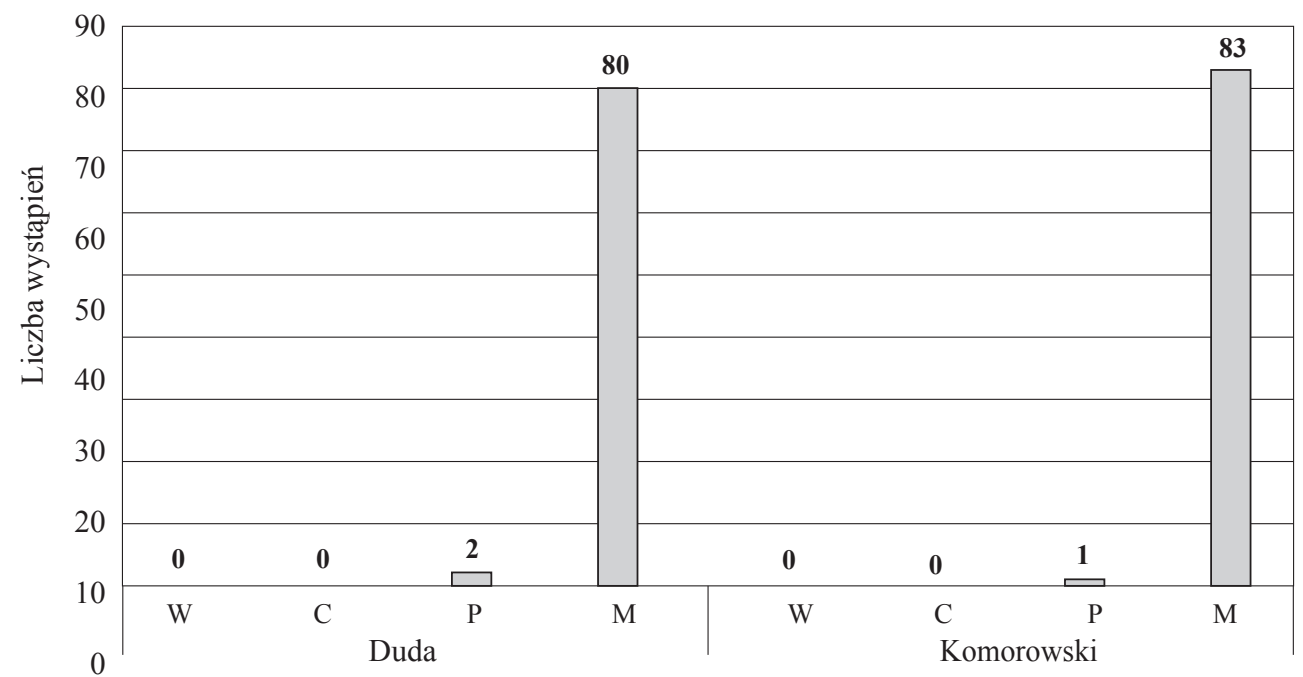

Źródło: Opracowanie własne.

Wykres 8. Czas (w sekundach) wypowiedzi kandydatów w „Wiadomościach" TVP w okresie poprzedzającym II turę głosowania, okres od 11 do 23 maja 2015 roku

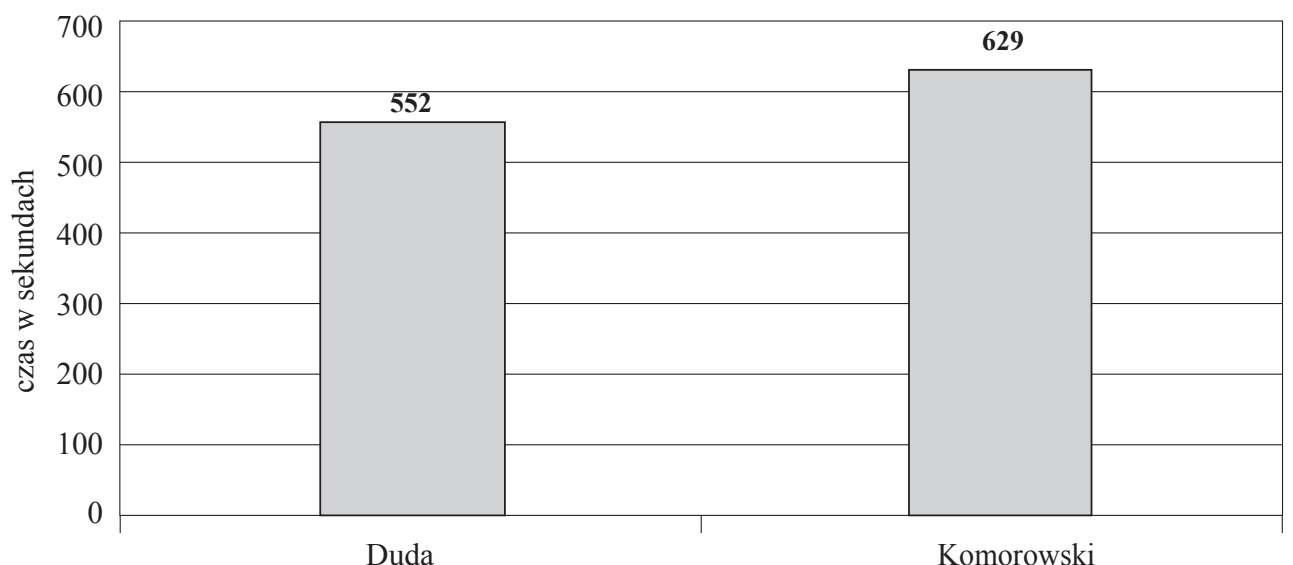

Źródło: Opracowanie własne. 
W dalszej części badania poddano analizie wydźwięk newsów, w których mówiono o kandydatach na urząd prezydenta. Szczegółowe wyniki prezentuje poniższy wykres. Wynika z nich w sposób jednoznaczny, że w zakresie prezentacji każdego z kandydatów przeważają newsy o charakterze neutralnym. Jednak tylko u jednego z kandydatów, Pawła Tanajno, któremu „Wiadomości” TVP w ogóle poświęciły bardzo mało uwagi, wszystkie newsy dotyczące jego osoby, miały charakter neutralny. Warto jednak zwrócić uwagę, że to właśnie w przypadku kandydatów, którym poświęcono najmniej uwagi, rzadko pojawiały się newsy wartościujące w sposób jednoznaczny, pozytywnie lub negatywnie. W przypadku Grzegorza Brauna i Mariana Kowalskiego poza newsami o wydźwięku neutralnym pojawiły się także materiały o charakterze ambiwalentnym, zaś Jacek Wilk raz został przedstawiony negatywnie.

W grupie kandydatów drugiego planu wyraźne jest zróżnicowanie w sposobie ich prezentacji, mimo ogólnej wskazanej już przewagi newsów neutralnych. Kandydatem prezentowanym wyłącznie neutralnie lub korzystnie był Adam Jarubas, w jego przypadku nie odnotowano żadnych newsów o charakterze negatywnym czy ambiwalentnym. $Z$ kolei kandydatem, $w$ tej grupie, prezentowanym najgorzej była Magdalena Ogórek, w przypadku której aż 8 newsów zostało zakwalifikowanych jako materiał o wydźwięku negatywnym. Jednocześnie uwagę zwraca fakt, że w okresie badania poprzedzającym pierwszą turę głosowania żadnemu $\mathrm{z}$ jedenastu kandydatów, nie poświęcono aż tyle materiałów o wydźwięku negatywnym. Pomiędzy ogólnie pozytywnym wydźwiękiem materiałów na temat Adama Jarubasa i negatywnym na temat Magdaleny Ogórek plasują się materiały dotyczące Janusza Korwin-Mikkego, Janusza Palikota oraz Pawła Kukiza. W przypadku Janusza Palikota część newsów było nacechowanych określoną intencją nadawczą -2 newsy miały wydźwięk pozytywny, 1 negatywny, a aż 8 ambiwalentny. W przypadku Korwin-Mikkego i Kukiza nie wystąpiły ani razu newsy jednoznacznie korzystne, występowały zaś materiały o charakterze negatywnym lub ambiwalentnym. Reasumując, należy podkreślić, że w grupie kandydatów drugiego planu zawsze największą grupę stanowiły newsy neutralne, 96\% w przypadku Adama Jarubasa, 73\% Janusza Korwin-Mikkego, 67\% Janusza Palikota, 58\% Magdaleny Ogórek i 57\% Pawła Kukiza. W przypadku części kandydatów występuje jednak znaczny odsetek, sięgający nawet ponad $40 \%$ newsów, które nie miały charakteru neutralnego.

Z uwagi na wynik pierwszej tury wyborów, szczególną uwagę warto zwrócić na wydźwięk materiałów dotyczących dwóch głównych pretendentów do fotela prezydenta RP. W przypadku każdego z nich występuje przewaga newsów neutralnych, których odsetek wśród wszystkich newsów dotyczących kandydata wynosił odpowiednio $64 \%$ w przypadku Andrzeja Dudy oraz 76\% w przypadku Bronisława Komorowskiego. Wyraźna pozostaje jednak tendencja w zakresie oceny kandydatów. W przypadku Andrzeja Dudy występują newsy prezentujące go w sposób niekorzystny lub ambiwalentny, odpowiednio $15 \%$ i $21 \%$ wszystkich newsów na temat kandydata, nie wystąpił natomiast żaden news prezentujący Dudę w korzystnym świetle. $Z$ odwrotną tendencją mamy do czynienia w przypadku Bronisława Komorowskiego. Nie wystąpił ani jeden news, który miałby wydźwięk negatywny, $12 \%$ newsów miało wydźwięk korzystny dla urzędującego prezydenta, zaś $12 \%$ ambiwalentny. 


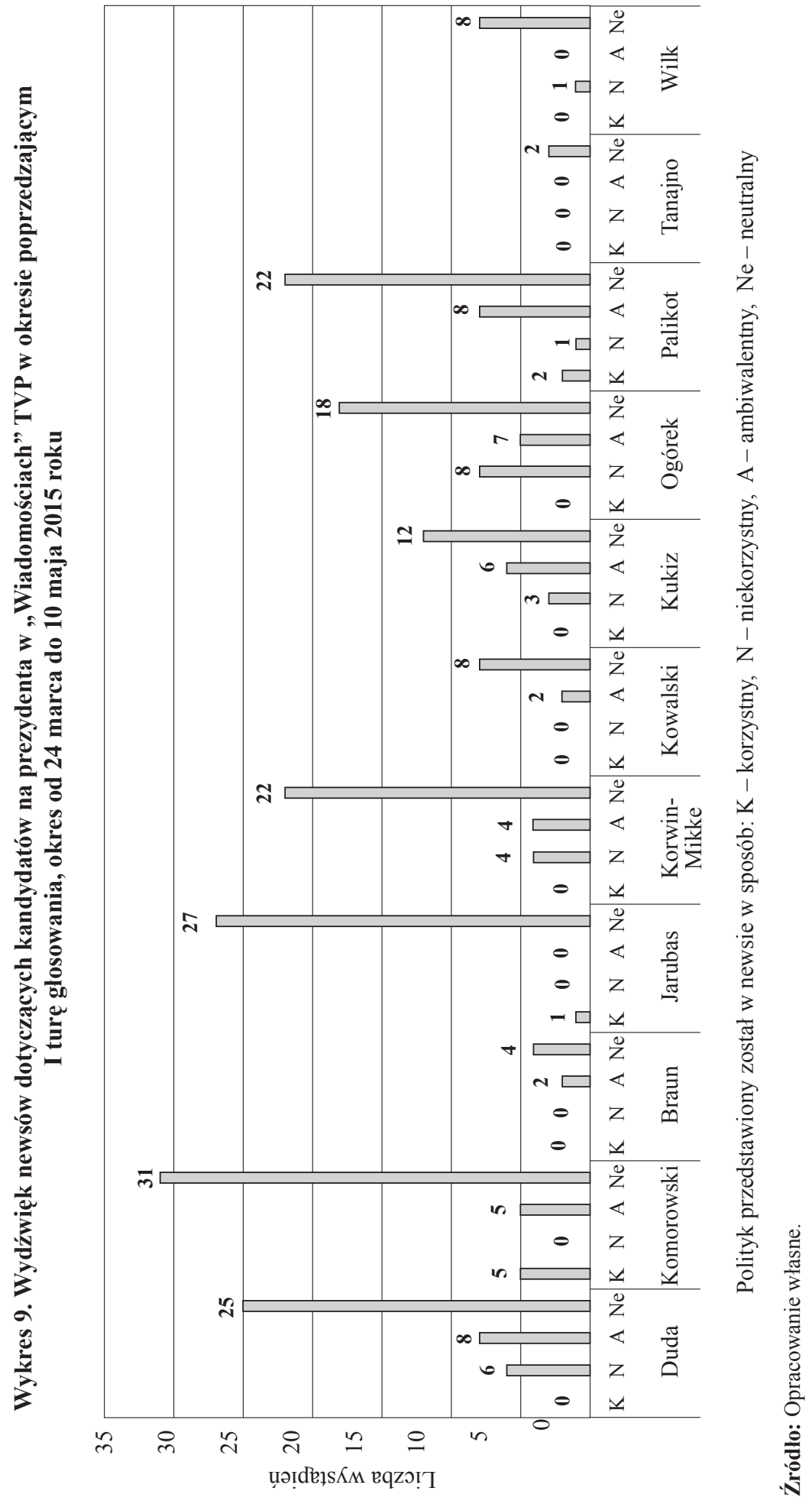


Wydźwięk materiałów poświęconych Andrzejowi Dudzie i Bronisławowi Komorowskiemu po pierwszej turze wyborów prezydenckich pozwala wskazywać na podobny trend, jaki występował w poprzednim analizowanym okresie. Szczegóły prezentuje poniższy wykres.

Wykres 10. Wydźwięk newsów dotyczących kandydatów na prezydenta w „Wiadomościach” TVP w okresie poprzedzającym II turę głosowania, okres od 11 do 23 maja 2015 roku

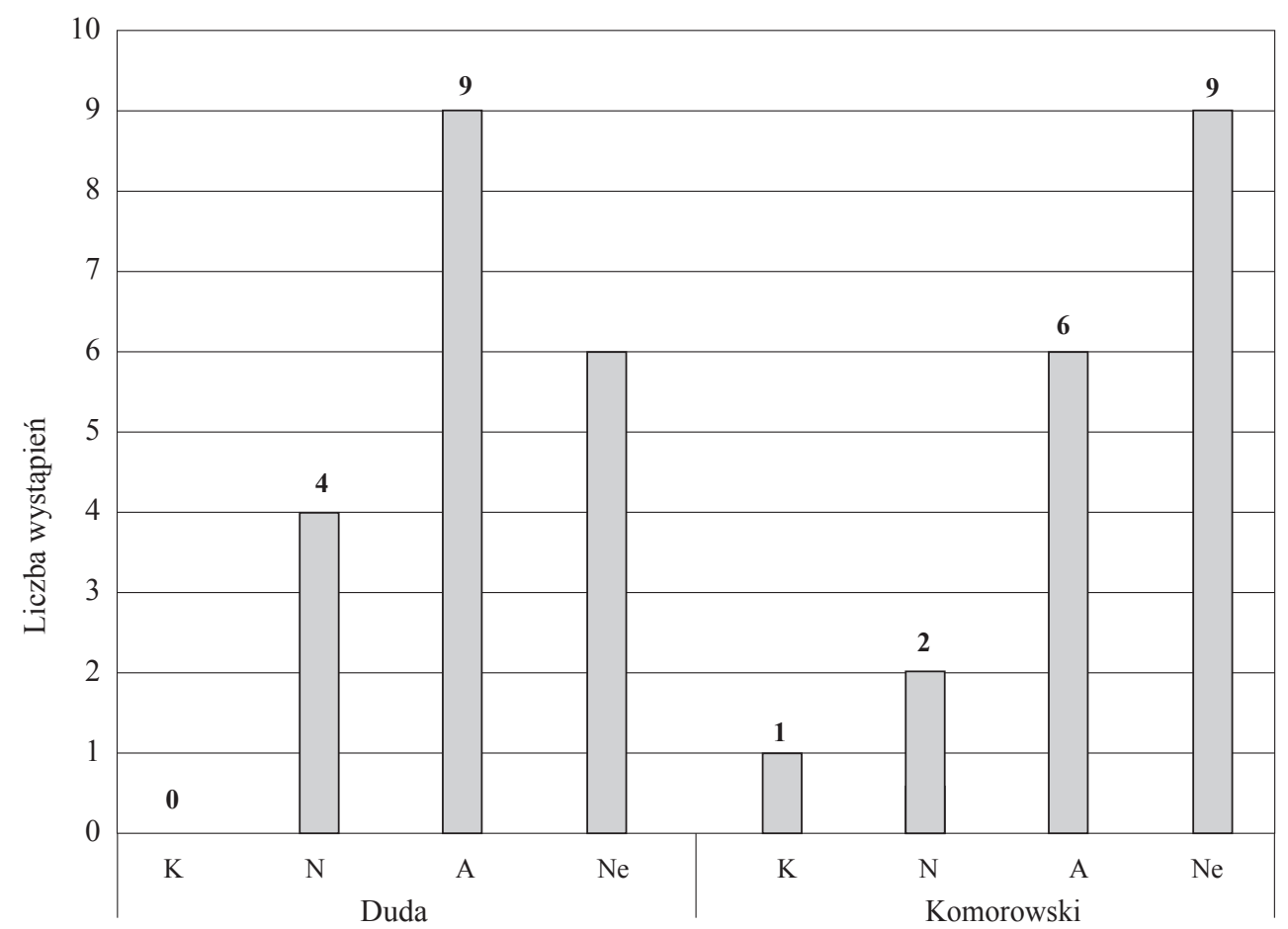

Polityk przedstawiony został w newsie w sposób: K - korzystny, $\mathrm{N}$ - niekorzystny, A - ambiwalentny, Ne - neutralny

Źródło: Opracowanie własne.

W przypadku jednego z kandydatów, Andrzeja Dudy, ponad połowa newsów nie była neutralna (68\%), zaś w przypadku Bronisława Komorowskiego dokładnie co drugi news nie miał neutralnego wydźwięku. W sposobie relacjonowania kampanii wyborczej urzędującego prezydenta nastąpiła wyraźna zmiana w porównaniu z okresem sprzed I tury głosowania, pojawiły się newsy o wydźwięku negatywnym (11\%), ambiwalentnym (33\%) i tylko jeden news miał wydźwięk korzystny (6\%). Z kolei w przypadku Andrzeja Dudy, podobnie jak w przypadku okresu przed pierwszą turą, nie pojawił się ani jeden news jednoznacznie korzystny, dwukrotnie częściej niż w przypadku rywala pojawiły się newsy o wydźwięku niekorzystnym, natomiast niemal połowa materiałów poświęconych Dudzie w okresie pomiędzy pierwszą a drugą turą wyborów miała wydźwięk ambiwalentny. 


\section{Wnioski}

Zaprezentowane wyniki badań dowodzą, że w „Wiadomościach” TVP nie można mówić o pełnej równowadze w zakresie widoczności i wydźwięku materiałów poświęconych kandydatom w prezydenckiej kampanii wyborczej. Należy zwrócić przy tym uwagę, że w przypadku polskiego publicznego nadawcy nie mamy do czynienia, jak w niektórych państwach, $\mathrm{z}$ istnieniem równowagi medialnej dotyczącej relacjonowania kampanii narzuconej przez system polityczny, normy czy rozwiązania instytucjonalne. Zasady takie często występują w państwach, w których istnieją dwaj dominujący aktorzy polityczni (systemy dwupartyjne lub dwublokowe) lub funkcjonują stosowne regulacje precyzujące sposób nagłaśniania kampanii wyborczej (Hopmann, Van Aelst i in., 2011, s. 106). Tym samym sposób relacjonowania kampanii wyborczej w „Wiadomościach” TVP zależy od rutyny dziennikarskiej i przekonań redakcji.

Badania empiryczne dowodzą, że w przypadku braku narzuconych rozwiązań normatywnych o częstotliwości prezentowania kandydata oraz przychylności mediów decydują: znaczenie kandydata lub partii politycznej na scenie politycznej mierzone obecnym lub spodziewanym poparciem, atrakcyjność polityka i jego charyzma oraz orientacja polityczna (Schoenbach, De Ridder, Lauf, 2001, s. 519). Wyniki przeprowadzonych badań silnie korespondują z danymi empirycznymi pochodzącymi z analiz przeprowadzonych w czasie kampanii wyborczych w Holandii i Niemczech. Widoczność medialna kandydatów, na co już wskazano, pozwoliła podzielić ich na trzy grupy: wiodących, drugiego planu i pomijanych. Najwięcej uwagi poświęcono już przed pierwszą turą głosowania tym kandydatom, którzy następnie dostali się do drugiej tury, zdecydowanie mniejszą szansę na obecność w mediach mieli kandydaci drugiego planu, natomiast czwórka kandydatów zamykających sondaże wyborcze niezwykle rzadko pojawiała się w „Wiadomościach” TVP. Wydaje się zatem, że czynnikiem kluczowym pozostawała rola kandydata na scenie politycznej i mierzona sondażami szansa na zwycięstwo w wyborach lub przynajmniej dostanie się do drugiej tury.

Czynnikiem determinującym w dużym stopniu obecność, ale i wydźwięk w sposobie prezentowania kandydata była jego atrakcyjność medialna. Tym tłumaczyć należy częstą obecność i względnie przychylne nagłaśnianie działań Janusza Palikota, kandydata który ostatecznie osiagnął bardzo niski wynik wyborczy. Podobnie, często nagłaśniana i negatywnie komentowana była Magdalena Ogórek. Jej zachowania i wypowiedzi, w szczególności manifestacyjny wręcz dystans do środowiska politycznego, które zaproponowało jej kandydaturę, czyniło ją z jednej strony ciekawostką kampanii, z drugiej strony obiektem złośliwości i cynicznych uwag, wartościujących jej kandydaturę negatywnie. W podobny sposób jako kandydaci medialnie atrakcyjni, a to za sprawą swej oryginalności, traktowani byli Paweł Kukiz oraz Janusz Korwin-Mikke.

Wreszcie trzecim czynnikiem, którego rola również pozostaje widoczna w sposobie prezentowania kandydatów jest ich orientacja polityczna. Nie należy zapominać, iż TVP jako publiczny nadawca pozostaje w najściślejszych relacjach z rządzącym obozem politycznym. Wobec faktu, iż prezydencka kampania wyborcza przypadała na okres ósmego roku rządów koalicji Platformy Obywatelskiej oraz Polskiego Stronnictwa Ludowego, można było spodziewać się, że kandydaci związani z tymi partiami politycznymi będą mogli liczyć na szczególną przychylność, a ich główni konkurenci na mniejszą obecność 
w programie i mniej korzystny sposób prezentacji. Czynnik ten w szczególnym stopniu wydaje się thumaczyć sposób, w jaki prezentowano Adama Jarubasa, któremu poświęcono relatywnie dużo czasu, a materiały poświęcone jego kandydaturze miały charakter neutralny bądź korzystny.

Ostatni ze wskazanych czynników wydaje się przesądzać także o widoczności i wydźwięku newsów prezentujących dwóch głównych kandydatów na urząd prezydenta. Zgodnie z oczekiwaniami, częściej, dłużej i korzystniej prezentowano Bronisława Komorowskiego, zaś rzadziej, krócej i mniej korzystnie Andrzeja Dudę. Warto jednak wskazać kilka dodatkowych uwag odnoszących się do sposobu prezentacji wskazanych polityków. Podkreślić należy, że zwykle polityk sprawujący urząd, czyli inkumbent, prezentowany jest w mediach lepiej, korzystniej, a w szczególności częściej niż pretendent, czyli kandydat, który dopiero ubiega się o urząd. Zjawisko to, analizowane zarówno $\mathrm{w}$ wymiarze teoretycznym, jak i badane na poziomie empirycznym, potwierdza istnienie tzw. „bonusa inkumbenta” czy „bonusa kanclerskiego” (Hopmann, de Vreese, Albæk, 2011, s. 264 i n.). Część newsów prezentujących Bronisława Komorowskiego, zwłaszcza w okresie przed pierwszą turą głosowania, prezentowała go jedynie jako głowę państwa wykonującą swoje bieżące obowiązki i w tym kontekście przyjąć można, że prezydent byłby pokazywany także w sytuacji, gdyby nie był jednocześnie kandydatem.

Interesująca pozostaje także tendencja dotycząca ilości czasu poświęcanego kandydatom oraz wydźwięku materiałów na ich temat w okresie przed i po pierwszej turze głosowania. Wydaje się, że wraz ze wzrostem szans Andrzeja Dudy na objęcie funkcji prezydenta RP, „Wiadomości” TVP zaczęły poświęcać mu więcej czasu, a także przedstawiać materiały o negatywnym wydźwięku na temat Bronisława Komorowskiego. Należy więc przyjąć, że nawet jeśli „Wiadomości” TVP faworyzowały urzędującego prezydenta, po pierwszej turze głosowania czyniły to zdecydowanie słabiej. W badanym okresie przed pierwszą turą wyborów wypowiedzi Andrzeja Dudy w programie zajęły $35 \%$ czasu wypowiedzi dwóch głównych kandydatów, a już w okresie przed drugą turą głosowania $47 \%$.

Reasumując, stwierdzić należy, że „Wiadomości” TVP prezentowały kandydatów w czasie prezydenckiej kampanii wyborczej według własnej logiki. Kandydaci nie mieli takich samych szans na obecność w głównym telewizyjnym programie informacyjnym TVP. Decydującą rolę odgrywało ich miejsce na scenie politycznej mierzone wynikami sondaży oraz atrakcyjność medialna. W zakresie sposobu prezentowania głównych rywali mówić można o słabym faworyzowaniu urzędującego prezydenta, co jednak, jak pokazały wyniki wyborów, nie uniemożliwiło zwycięstwa jego konkurentowi. W związku z licznymi wskazaniami płynącymi ze strony sztabu wyborczego Andrzeja Dudy, że kampania wyborcza była relacjonowana niekorzystnie dla tego polityka, zasadne wydaje się kontynuowanie badań nad sposobem nagłaśniania prezydenckich kampanii wyborczych. Zmiany, jakie dokonały się w TVP po wyborach parlamentarnych, każą z wielką uwagą śledzić kolejne wybory i sposób ich relacjonowania przez „Wiadomości” TVP. Interesująca wydaje się w szczególności możliwość powtórzenia badania w oparciu o dane empiryczne pozyskane w czasie następnych wyborów prezydenckich, przy użyciu identycznej metodologii. Wyniki takich badań pozwolą ocenić, czy zmiany w TVP doprowadziły do większej równowagi czy też do większej stronniczości w relacjonowaniu prezydenckiej kampanii wyborczej niż miało to miejsce w 2015 roku. 


\section{Bibliografia}

Berelson B. (1952), Content Analysis in Communication Research, The Free Press, New York.

Esser F., Strömbäck J., De Vreese C. H. (2011), Reviewing key concepts in research on political news journalism: Conceptualizations, operationalizations, and propositions for future research, „Journalism”, vol. 13, nr 2.

Farnsworth S. J., Lichter S. R. (2011), The Nightly News Nightmare: Media Coverage of U.S. Presidential Elections, 1988-2008, Rowman \& Littlefield, Lanham-Boulder-New York-Toronto-Plymouth.

Gulati G. J., Just M. R., Crigler A. N. (2004), News Coverage of Political Campaigns, w: Handbook of Political Communication Research, red. L. L. Kaid, Lawrence Erlbaum Associates, MahwahNew Jersey-London.

Hjarvard S. (2013), The Mediatization of Culture and Society, Routledge, London-New York.

Hopmann D. N., de Vreese C. H., Albæk E. (2011), Incumbency Bonus in Election News Coverage Explained: The Logics of Political Power and the Media Market, „Journal of Communication”, vol. $61, \mathrm{nr} 2$.

Hopmann D. N., Van Aelst P., Legnante G. (2011), Political balance in the news: A review of concepts, operationalizations and key findings, ,Journalism”, vol. 13, nr 2.

Kolczyński M., Mazur M. (2007), Wojna na wrażenia: strategie polityczne i telewizja w kampaniach wyborczych 2005 r. w Polsce, Wydawnictwo Sejmowe, Warszawa.

Łódzki B. (2010), Ustanawianie agendy mediów podczas kampanii wyborczych w 2005 roku, Wydawnictwo Uniwersytetu Wrocławskiego, Wrocław.

Maier M., Strömbäck J., Kaid L. L. (red.) (2011), Political Communication in European Parliamentary Elections, Ashgate, Farnham.

Mazzoleni G. (2008), Mediatization of Society, w: The International Encyclopedia of Communication, red. W. Donsbach, Blackwell Publishing, Malden-Oxford-Carlton.

Mazzoleni G. (2015), Mediatization of Politics, w: The Concise Encyclopedia of Communication, red. W. Donsbach, Wiley, Malden-Oxford-Chichester.

Nowak E., Riedel R. (2008), Agenda setting, priming, news framing. Analiza porównawcza telewizyjnych audycji informacyjnych TVN $i$ TVP1 $w$ okresie kampanii przedwyborczych $w$ Polsce 2005 i 2007 r., „Zeszyty Prasoznawcze”, nr 1-2.

Raport z badań TNS OBOP (2015), Wiarygodne informacje - czy sq dziś w cenie?, http://www.tnsglobal.pl/wp-content/blogs.dir/9/files/2015/04/K.031_Wiarygodne-informacje_O03a-15.pdf.

Schoenbach K., De Ridder J., Lauf E. (2001), Politicians on TV News: Getting attention in Dutch and German election campaigns, „European Journal of Political Research”, vol. 39, nr 4.

Strömbäck J., Esser F. (2014a), Making sense of the mediatization of politics, „Journalism Studies”, vol. $15, \mathrm{nr} 3$.

Strömbäck J., Esser F. (2014b), Mediatization of Politics: Towards a Theoretical Framework, w: Mediatization of Politics. Understanding the Transformation of Western Democracies, red. F. Esser, J. Strömbäck, Palgrave Macmillan, Basingstoke.

Strömbäck J., Kaid L. L. (red.). (2008), The Handbook of Election News Coverage Around the World, Routledge, New York-London.

\section{Coverage of the presidential election campaign in 2015 by „Wiadomości” TVP1: balanced oraz biased?}

\section{Summary}

In contemporary democratic state there is expected the mass media to serve several roles: informing voters about the candidates and their ideas, interpreting actions of candidates and their opponents, con- 
trolling those in power and mobilizing voters politically. There is very important relationship between knowledge about candidates, evaluation of candidates, decision about voting and candidate coverage in media. The television is still very important source of political information. $81 \%$ of respondents indicated that TV news programs are the main source of political news.

The article presents the results of media content analysis of „Wiadomości” TVP1 before presidential election in 2015 in Poland. The purpose of the research was to evaluate if the campaign coverage was balanced or biased. There was visibility of candidates and media's favorability examined in the analysis of the most watched TV news program.

Key words: partisan media bias, political balance, TV News Programs, coverage of presidential elections, content analysis 
